\title{
PENGARUH LAMA PENYIMPANAN TERHADAP KANDUNGAN SERAT KASAR TEPUNG BIJI LAMUN (Enhalus acoroides), SERTA IMPLIKASINYA BAGI PEMBELAJARAN MASYARAKAT DI PULAU OSI KABUPATEN SERAM BAGIAN BARAT
}

\author{
Prelly.M.J.Tuapattinaya \\ Program Studi Pendidikan Biologi, Jurusan Pendidikan Matemarika dan Ilmu \\ Pengetahuan Alam, Fakultas keguruan dan ilmu pendidikan Universitas Pattimura \\ 085243766957,E-mail: frelly_tuapattinaya@yahoo.co.id
}

\begin{abstract}
Abstrak: Hasil penelitian menunjukan bahwa terdapat pengaruh lama penyimpanan terhadap kadar serat tepung biji lamun yakni semakin lama penyimpanan maka kadar serat tepung pun mengalami penurunan dan terdapat perbedaan serat kasar yang signifikan antara tepung biji lamun 0 bulan dengan tepung biji lamun yang disimpan selama 2 bulan, 4 bulan dan 6 bulan tetapi tidak terdapat perbedaan yang signifikan antara tepung biji lamun yang disimpan selama 2 bulan dengan yang disimpan selama 4 bulan dan 6 bulan serta tidak terdapat perbedaan yang disimpan selama 4 bulan dan disimpan selama 6 bulan.
\end{abstract}

Kata Kunci: Lamun, Kadar Serat, Lama Penyimpanan.

\section{THE INFLUENCE OF LONG STORAGE AGAINST COARSE FIBER CONTENT FLOUR SEEDS (Enhalus acoroides) AS WELL AS THE IMPLICATIONS FOR LEARNING THE COMMUNITY ON THE ISLAND OF OSI}

\begin{abstract}
The results of the study express its strongest that there is the influence of long storage against the nature of all that the fibers of the starchy seagrass beds of bond issuance will be that you may be old storage so the nature of all that meal and bread dough that fiber has also been its dips and there was a gap in coarse fibers in welfare between the starchy seagrass beds 0 of the month with the starchy seagrass beds that is stored as long as 2 months, 4 the moon and 6 the moon but there is no significant difference between the starchy seagrass beds that is stored as long as 2 the moon by which stored for 4 the moon and 6 months and there are no a difference that is stored for 4 the moon and stored for 6 months.
\end{abstract}

Keywords: Seagrass Beds, The Fibers, Long Storage 
Indonesia dengan kekayaan alam berupa bahan pangan lokal, mempunyai potensi gizi dan komponen bioaktif yang baik, namun belum dimanfaatkan secara optimal. Hal ini disebabkan oleh kurangnya pengetahuan masyarakat akan manfaat komoditas pangan tersebut. Salah satu dari bahan pangan tersebut adalah tumbuhan lamun. Lamun hidup di perairan dangkal yang agak berpasir, sering juga dijumpai di terumbu karang dan membentuk komunitas yang lebat hingga menjadi padang lamun yang cukup luas. Padang lamun ini merupakan ekosistem yang sangat tinggi produktifitas organiknya. Di padang lamun ini hidup bermacam-macam biota laut (Nontji, 2002). Di perairan Indonesia terdapat 13 jenis lamun (Kiswara, 2009), Salah satu jenis lamun tersebut adalah lamun jenis Enhalus acoroides.

Enhalus acoroides merupakan salah satu jenis lamun yang paling melimpah di perairan Indonesia dan mempunyai ukuran morfologi yang besar (den Hartog, 1970). Menurut Tomascik et al, dalam Hasanuddin (2013), Enhalus acoroides merupakan spesies yang paling umum ditemukan mulai dari sedimen halus hingga lumpur, namun di sedimen sedang hingga kasar ia tetap dapat tumbuh sebab akar-akarnya panjang dan kuat sehingga mampu menyerap makanan dengan baik dan dapat berdiri kokoh. Semakin panjang suatu akar maka akan semakin optimal pengambilan nutrient dari dalam substrat (Jumin, dalam Steven, 2013).

Kelebihan yang dimiliki oleh Enhalus acoroides yaitu pertumbuhannya lebih cepat dibandingkan jenis lamun yang lainnya. Selain itu keistimewaan secara ekonomis adalah buah Enhalus acoroides dapat dimanfaatkan sebagai bahan makanan dan memiliki nilai gizi (Wilis et al, 2003). Masyarakat Maluku yang hidup di daerah pesisir sebagian besar telah memanfaatkan biji lamun sebagai bahan makanan. Diantaranya yaitu masyarakat di desa Waai kabupatan Maluku Tengah (Salamoni, 2014). Selain itu, penelitian yang dilakukan oleh (Wakano, 2013) melaporkan bahwa buah lamun Enhalus acoroides telah lama dimanfaatkan oleh masyarakat Lomin Seram Bagian Timur, yaitu dengan cara memakan mentah atau direbus. Kebiasaan masyarakat memanfaatkan biji lamun Enhalus acoroides sebagai sumber makanan hanya pada saat-saat tertentu saja, yaitu pada saat musim timur, maka buah lamun Enhalus acoroides yang menjadi sumber protein untuk kehidupan sehari-hari dan bukan untuk mendapatkan penghasilan tambahan.salah satu perairan pantai di Maluku yang memiliki padang lamun cukup luas yaitu perairan pantai pulau Osi.

Pulau Osi merupakan pulau yang wilayah perairannya kaya akan berbagai potensi sumberdaya hayati laut termasuk ekosistem padang lamun. Namun, cara masyarakat mengonsumsi biji lamun tidak jauh berbeda dengan masyarakat di Desa Waai Maluku Tengah dan Desa Lomin SBB yaitu di makan mentah atau dimasak menjadi sayur. Dengan demikian pemanfaatan biji lamun oleh masyarakat Maluku hanya terdapat pada pemenuhan kebutuhan sehari-hari. Oleh karena itu, perlu ada cara agar masyarakat dapat mengolah biji lamun menjadi sesuatu bahan jadi yang dapat bertahan lama dan memiliki 
nilai jual serta kandungan gizi . Salah satu cara alternatif yang dapat dilakukan adalah dengan mengolah biji lamun menjadi produk setengah jadi (tepung). Tepung merupakan salah satu cara pengolahan hasil panen, terutama untuk komoditas pangan yang berkadar air tinggi, seperti umbi-umbian dan buah-buahan. Keuntungan lain dari pengolahan produk setengah jadi yaitu sebagai bahan baku yang fleksibel untuk industri pengolahan lanjutan, aman dalam distribusi, serta hemat ruang dan biaya penyimpanan (Kartining, 2012). Menurut Titiek et al, (2005), pemanfaatan buah menjadi tepung memiliki kelebihan diantaranya: pemanfaatan lebih fleksibel (dapat digunakan sebagai bahan subtitusi tepung terigu) dan umur simpan lebih panjang.

Umur simpan merupakan hal yang penting untuk mengetahui keamanan suatu produk makanan. Oleh karena itu dalam proses penyimpanan salah satu hal yang perlu diperhatikan adalah lama penyimpanan bahan makanan untuk menentukan bahan makanan tersebut masih layak untuk dikonsumsi atau tidak, (Indrianty, 2010). Tepung dinyatakan layak konsumsi apabila kandungan gizinya memenuhi standar mutu (SNI) dan salah satu komponen dalam tepung yang dapat dianalisis yaitu kadar serat kasar.

Hermayati $d k k$ (2006) mengatakan bahwa serat kasar merupakan residu dari bahan makana atau hasil pertanian setelah diperlakukan dengan asam atau alkali mendidih, dan terdiri dari selulosa, dengan sedikit lignin dan pentosa, dan menurut Winarno, (2004), serat dalam pangan tidak dapat dicerna oleh tubuh tetapi mempunyai sifat positif bagi gizi dan metabolism serta dapat mencegah berbagai penyakit seperti jantung koroner, sembelit, diare, wasir dan kanker usus besar. Selain itu, penentuan serat kasar pada bahan pangan sangat peting dalam peilaian kualitas bahan pangan karena angka ini merupakan indeks dalam mentukan nilai gizi bahan makanan. Serat kasar juga dapat dipakai untuk menentukan kemurnian bahan dan efisiensi proses (Sudarmadji $d k k$., 1996). Penelitian ini bertujuan untuk Menganalisis kadar serat kasar tepung biji lamun Enhalus acoroides dari pulau Osi dan mengetahui pengaruh lama penyimpanan terhadap kadar serat tepung biji lamun Enhalus acoroides dari pulau Osi.

\section{METODE PENELITIAN}

Penelitian ini dilaksanakan pada bulan Mei-November 2015 di Laboratorium Kimia Dasar Fakultas MIPA, Universitas Pattimura, Ambon. Bahan yang digunakan dalam penelitian ini adalah tepung biji lamun digunakan sebagai bahan dasar analisis, Etanol $96 \%$ sebagai pelarut, $\mathrm{H}_{2} \mathrm{SO}_{4} 1,25 \%$ untuk menghidrolisis sampel, dan $\mathrm{NaOH}$ $3,25 \%$ digunakan untuk membebaskan gas amoniak dari larutan (KP). Alat yang digunakan ini adalah Neraca analitik, Gelas piala $250 \mathrm{ml}$, Kertas saring, Erlemeyer 250 $\mathrm{ml}$, Oven, Corong, Cawan penguap, dan Kamera

\section{Tahapan Persiapan}

Dalam tahap persiapan ada beberapa hal yang perlu dilakukan yaitu

a. Meninjau tempat penelitian 
b. Menyiapkan alat dan bahan yang akan digunakan dalam penelitian

\section{Tahapan pelaksanaan}

\section{a. Pembuatan tepung biji lamun (Rosady, 2004)}

Bahan baku yang digunakan adalah biji lamun Enhalus acoroides. Tahap-tahap pembuatannya adalah sebagai berikut: Buah lamun dibelah kemudian di lakukan sortasi untuk memilih biji lamun yang baik dan membuang biji lamun yang rusak atau pecah/remuk, kemudian dicuci bersih, diiris tipis dan dikeringkan. Pengeringan dengan oven pada suhu $55^{\circ} \mathrm{C}$. Tumbuk dan ayak untuk mendapatkan tepung biji lamun.

b. Analisis Serat Kasar Berdasarkan SNI 01-2891-1992 dilakukan sebagai berikut:

Timbang sampel sebanyak 2-4 gram secara teliti dengan neraca analitik digital. Pindahkan sampel ke dalam gelas piala $250 \mathrm{~mL}$. Untuk pembebasan lemak, tambahkan etanol $96 \%$ sebanyak $15 \mathrm{~mL}$, lalu aduk dan kemudian diamkan beberapa menit. Tuangkan larutan tersebut dengan kertas saring ke dalam Erlenmeyer $250 \mathrm{~mL}$. Lakukan proses tuang dua kali dengan etanol $96 \%$ tersebut, dimana untuk ketiga kalinya endapan disertakan dalam penyaringan. Atau dapat juga pembebasan lemak sisa dari ekstraksi lemak dengan cara soklet atau cara mengaduk, mengendap tuangkan sampel dalam pelarut organik. Lalu, angkat kertas saring yang telah berisi padatan dan keringkan. Tambahkan $\pm 50 \mathrm{~mL}$ larutan $\mathrm{H}_{2} \mathrm{SO}_{4} 1,25 \%$ ke dalam erlenmeyer dan diaduk. Pasang pendingin tegak pada mulut Erlenmeyer. Panaskan larutan refluk selama 30 menit dengan pemanas air. Jika telah selesai, langsung tambahkan $\pm 50 \mathrm{~mL}$ larutan $\mathrm{NaOH} 3,25 \%$ Lakukan pemanasan larutan refluk kembali selama 30 menit. Jika telah selesai, saring larutan dalam keadaan panas dengan kertas saring yang telah ditimbang konstan sebelumnya dengan menggunakan corong. Lakukan pencucian dengan $\mathrm{H}_{2} \mathrm{SO}_{4} \quad 1,25 \%$ panas, air panas, dan terakhir dengan etanol $96 \%$ (masing-masing $25 \mathrm{~mL}$ ). Diangkat endapan dan kertas saring, kemudian pindahkan ke cawan penguap yang telah dikonstankan beratnya terlebih dahulu dan mengeringkannya pada suhu $105^{\circ} \mathrm{C}$ di dalam oven, kemudian mendinginkannya dan menimbangnya sampai bobot tetap.

Penelitian dilakukan dengan menggunakan Rancangan Acak Lengkap faktor tunggal yaitu lama penyimpanan terhadap kadar serat tepung biji lamun Enhalus acoroides dengan 3 kali pengulangan pada masing-masing sampel dengan teknik pengumpulan data yang digunakan dalam penelitian ini adalah data primer yaitu dengan menggunakan data yang diperoleh dari hasil penelitian di laboratorium. Dan data sekunder yaitu data yang diperoleh dari berbagai kajian literatur yang berhubungan dengan permasalahan dalam penelitian ini. Hasil dihitung dengan Analisa statistika menggunakan analisis satu jalur (ONE WAY ANNOVA), pada taraf signifikan $(\alpha) 0.05$ dan apabila terjadi perbedaan perhitungan yang sangat signifikan, maka akan dilanjutkan dengan uji Tukey. Proses pengolahan data dalam penelitian ini dilakukan dengan bantuan program computer Statistical Package for Social Science (SPSS) 16,0. 


\section{HASIL DAN PEMBAHASAN}

Analisis kadar serat yang dilakukan terhadap tepung biji lamun dengan perlakuan yang berbeda yaitu tanpa penyimpanan nol (0) bulan, penyimpanan dua (2) bulan, empat (4) bulan dan enam (6) bulan, hasilnya dapat dilihat pada Tabel 1 berikut:

Tabel 1. Hasil Analisis Kadar Serat Tepung Biji Lamun

\begin{tabular}{|l|l|l|l|}
\hline $\begin{array}{c}\text { Lama } \\
\text { Penyimpanan }\end{array}$ & $\begin{array}{c}\text { Berat Sampel } \\
(\mathrm{g})\end{array}$ & $\begin{array}{c}\text { Berat Serat } \\
(\mathrm{g})\end{array}$ & $\begin{array}{c}\text { Kadar Serat } \\
(\%)\end{array}$ \\
\hline 0 bulan & 2,02 & 0,04 & 2,82 \\
& 2,04 & 0,07 & 2,88 \\
& 2,04 & 0,04 & 2,90 \\
\hline 2 bulan & 3,12 & 0,06 & 2,22 \\
& 3,18 & 0,06 & 2,04 \\
& 3,21 & 0,12 & 2,34 \\
\hline 4 bulan & 3,14 & 0,06 & 2,17 \\
& 3,16 & 0,06 & 2,20 \\
& 3,19 & 0,07 & 2,36 \\
\hline 6 bulan & 2,05 & 0,04 & 1,99 \\
& 2,10 & 0,04 & 2,07 \\
& 2,24 & 0,04 & 2,07 \\
\hline
\end{tabular}

Hasil analisis varians menunjukan bahwa lama penyimpanan tepung biji lamun berpengaruh terhadap kadar serat tepung biji lamun karena nilai hasil analisis data signifikan yaitu $0,000<0,05$. Hal ini berarti bahwa $\mathrm{H}_{1}$ diterima yaitu terdapat pengaruh lama penyimpanan terhadap kadar serat tepung biji lamun. Untuk mengetahui perbedaan antara masing-masing perlakuan maka dilakukan Uji lanjut yaitu Uji Tukey, sebagaimana ditunjukan pada Tabel 2

Tabel 2 Hasil Analisi Kadar Serat Tepung Lamun Menggunakan Uji Tukey

\begin{tabular}{|l|l|}
\hline Lama Penyimpanan & Rerata Kadar Serat Kasar Tepung \\
\hline 0 bulan & $2,8733^{\mathrm{b}}$ \\
\hline 2 bulan & $2,2533^{\mathrm{a}}$ \\
\hline 4 bulan & $2,2000^{\mathrm{a}}$ \\
\hline 6 bulan & $2,0467^{\mathrm{a}}$ \\
\hline
\end{tabular}

Keterangan: huruf yang sama pada kolom yang sama menunjukkan tidak berbeda nyata berdasarkan uji tukey pada taraf kepercayaan.

Berdasarkan hasil uji tukey pada tabel 2 dapat dilihat lama penyimpanan tepung biji lamun 0 bulan terlihat berbeda nyata dari lama penyimpanan tepung biji lamun 2, 4 dan 6 bulan dapat dilihat dari huruf pada kolom tabel yang berbeda. Sedangkan pada lama penyimpanan biji lamun 2 bulan menunjukkan hasil yang tidak berbeda nyata dengan lama penyimpanan 4 bulan dan 6 bulan begitu juga tidak berbeda nyata lama penyimpanan 4 bulan dengan lama penyimpanan 6 bulan yang dapat dilihat dari huruf pada kolom pada tabel yang sama. 
Serat kasar merupakan residu dari bahan makanan atau hasil pertanian setelah diperlakukan dengan asam atau alkali mendidih, dan terdiri dari selulosa, dengan sedikit lignin dan pentosa. Serat kasar juga merupakan kumpulan dari semua serat yang tidak bisa dicerna, komponen dari serat kasar ini yaitu terdiri dari selulosa, pentosa, lignin, dan komponen-komponen lainnya. Komponen dari serat kasar ini tidak mempunyai nilai gizi akan tetapi serat ini sangat penting untuk proses memudahkan dalam pencernaan di dalam tubuh agar proses pencernaan tersebut lancar (peristaltic) (Hermayati dkk, 2006). Makanan dengan kandungan serat kasar yang tinggi juga dapat mengurangi bobot badan (Bell et al, 1990).

Salah satu tanaman yang memiliki kandungan serat kasar adalah lamun Enhalus (Setyati et al, 2003). Biji Lamun Enhalus acoroides biasanya dikonsumsi oleh masyarakat hanya dengan cara memakan mentah atau direbus. (Salamoni, 2014); (Wakano, 2013) karena alasan itulah pada penelitian ini, peneliti memanfaatkan biji lamun Enhalus acoroides untuk diolah menjadi tepung agar dapat dikonsumsi dan disimpan dalam waktu yang lama. Selain itu, tumbuhan lamun di pulau osi dapat berbuah sepanjang tahun namun kelimpahannya hanya dapat dinikmati 6 bulan sekali. Hal inilah yang membuat peneliti perlu untuk melakukan perlakuan penyimpanan sampel agar dapat menentukan masa simpan yang baik dari tepung biji lamun sehingga masyarakat dapat menyimpan sebagai stok dan dapat dipakai sewaktu-waktu.

Prinsip analisis serat kasar yaitu sampel yang dihidrolisis dengan asam kuat dan basa kuat encer, sehingga karbohidrat, protein, dan zat-zat lain terhidrolisis dan larut, kamudian disaring dan dicuci dengan air panas yang mengandung asam dan alkohol, selanjutnya dikeringkan dan ditimbang (Hermayanti dkk., 2006). Dalam literatur dijelaskan bahwa serat kasar merupakan serat pangan yang tidak larut dalam asam maupun basa, oleh karena itu dalam penelitian ini, analisisnya dilakukan dengan penambahan $\mathrm{H}_{2} \mathrm{SO}_{4} 1,25 \%(0,255 \mathrm{~N})$ bertujuan melarutkan zat lain yang dapat larut dalam asam, demikian pula dengan penambahan $\mathrm{NaOH} 1,25 \%$ yang bertujuan untuk melarutkan zat-zat yang larut dalam basa yang tidak larut dalam asam, sedangkan penambahan $\mathrm{K}_{2} \mathrm{SO}_{4} 10 \%$ dan aquadest yang mendidih untuk menghilangkan kelebihan $\mathrm{NaOH}$ dalam residu.

Analisis tepung biji lamun dilakukan pada tepung yang belum disimpan (0) bulan dan tepung yang telah disimpan selama 2, 4 dan 6 bulan. Perbedaan waktu penyimpanan ini dilakukan untuk melihat seberapa besar berkurangnya kadar serat kasar dari 2 bulan sebelumnya. Berdasarkan hasil pada tabel 2 terlihat bahwa terdapat perbedaan yang signifikan antara tepung 0 bulan (tanpa penyimpanan) dengan tepung yang di simpan selama 2,4 dan 6 bulan dengan nilai signifikan 0.000, sehingga dilanjuti dengan uji tuckey yang menunjukkan nilai kadar serat kasar tertinggi pada lama penyimpanan 0 bulan dengan nilai 2.8733 dan nilai kadar serat kasar terkecil pada lama penyimpanan 6 bulan dengan nilai 2.0467. Hasil ini menunjukkan bahwa semakin lama penyimpanan tepung 
biji lamun akan berpengaruh pada kadar serat kasar pada tepung biji lamun. Hal ini dikarenakan tepung 0 bulan tidak melalui proses penyimpanan sehingga tidak terjadi perubahan oleh proses kimiawi pada tepung yakni air tidak terabsorbsi oleh tepung sehingga kadar serat masih tetap utuh atau terjaga. Berbeda dengan tepung yang telah disimpan selama 2, 4 dan 6 bulan yang telah melalui proses kimiawi selama proses penyimpanan sehingga menyebabkan berkurangnya kadar serat pada tepung. Hal ini juga berlaku untuk perlakuan peyimpanan tepung 2 bulan terhadap 4 dan 6 bulan juga antara penyimpanan 4 dan 6 bulan dimana kadar serat kasar tepung mengalami penurunan atau berkurang. Dengan demikian dapat dikatakan bahwa lama penyimpanan berpengaruh terhadap berkurangnya kadar serat kasar pada tepung biji lamun.

Chung et al, (2000) mengemukakan bahwa tepung memiliki sifat higroskopis (mudah menyerap air) sehingga jika tepung dikemas dengan kemasan yang rendah bariernya terhadap uap air maka kadar air pada tepung akan bertambah selama penyimpanan. Pada penelitian ini, kemasan yang digunakan adalah kemasan poliproplen yang memiliki daya tembus atau permeabilitas uap air yang rendah sehingga semakin lama waktu penyimpanan, kadar serat kasar pun meningkat. Kemasan yang sering digunakan untuk produk tepung-tepungan adalah LDPE dan PP. Permeabilitas polietilen densitas rendah (LDPE) terhadap uap air adalah sebesar $0.5 \mathrm{~g} / \mathrm{m} 2 \mathrm{hr} \mathrm{mmHg}$ dan permeabilitas polipropilen (PP) terhadap air adalah sebesar $0.185 \mathrm{~g} / \mathrm{m} 2 \mathrm{hr} \mathrm{mmHg}$. Namun menurut Robi'in, (2007) foil umumnya lebih baik jika disbanding plastik dari segi sifat kedap udara maupun uap air.

Labuza menjelaskan, (1982) menjelaskan bahwa kerusakan produk pangan dapat disebabkan oleh adanya penyerapan air oleh produk selama penyimpanan. Laju penyerapan air oleh produk pangan selama penyimpanan dipengaruhi oleh tekanan uap air murni pada suhu udara tertentu. Peningkatan kadar air tersebut disebabkan karena adanya penyerapan uap air dari lingkungan untuk mencapai kondisi kesetimbangan. Selain itu, adanya perbedaan kelembaban antara lingkungan dengan sampel tepung akan menyebabkan perbedaan tekanan parsial uap air. Perbedaan tekanan parsial uap air ini akan menyebabkan terjadinya perpindahan uap air dari daerah yang bertekanan tinggi ke daerah bertekanan rendah. Karena tekanan parsial atau kelembaban uap air lingkungan lebih besar dari tekanan parsial uap air sampel dalam kemasan, maka uap air akan berpindah ke dalam sampel tersebut (Mustafidah dkk, 2015).

Penurunan kandungan serat kasar pada penelitian ini bisa disebabkan juga oleh adanya pemecahan hemiselulosa karena hemiselulosa merupakan bagian dari serat kasar. Arief et al, (2008), menyatakan bahwa enzim hemiselulase dapat memecah hemiselulosa dan enzim hemiselulase itu diantaranya seperti glukanase, xylanase, galaktanase, mannase, galaktomannase, dan pentosanase. Hal ini sejalan dengan pendapat yang di kemukakan oleh Fennema, (1985) dimana kadar air dan aktivitas air dapat mempengaruhi sifat-sifat fisik dan sifat-sifat fisiko-kimia, perubahan-perubahan kimia, kerusakan 
mikrobiologis dan perubahan enzimatis terutama pada makanan. Hal tersebut dapat dilihat pada sifat fisik tepung yang mengalami perubahan warna selama proses penyimpanan 2, 4 dan 6 bulan. Dengan demikian dapat dikatakan bahwa semakin lama waktu penyimpanan pada tepung dapat menyebabkan meningkatkannya kadar air pada tepung yang berimbas pada menurunnya kadar serat kasar pada tepung. Brooker et al, (1992), menyatakan bahwa jika kelembaban udara relatif lebih tinggi dibandingkan kelembaban relatif bahan maka bahan akan menyerap air. Kadar air pada tepung (mocaf) yang lebih rendah menyebabkan lebih tahan terhadap pertumbuhan jamur yang dapat menyebabkan kerusakan. Dengan demikian, untuk menghindari berkurangnya kadar serat dan nutrisi dari tepung biji lamun maka tepung yang sudah jadi sebaiknya tidak disimpan tetapi langsung digunakan oleh masyarakat yaitu dengan mengolahnya menjadi produk makanan seperti kue, mie dan lainnya.

Serat mempunyai peran yang penting bagi kesehatan tubuh. Almatsier, (2009) menyatakan bahwa serat sangat penting dalam proses pencernaan makanan dalam tubuh. Kekurangan serat dapat menyebabkan konstipasi, apenaistis, alverculity, hemoroid, diabetes melitus, penyakit jantung koroner dan batu ginjal. Kekurangan serat juga dihubungkan dengan berbagai penyakit gastrointestinal. Wirjatmadi et al, (2002), menambahkan kebutuhan serat untuk manusia sangatlah bervariasi menurut pola makan dan tidak ada anjuran kebutuhan sehari secara khusus untuk serat makanan. Konsumsi serat rata-rata $25 \mathrm{~g} /$ hari dapat dianggap cukup untuk memelihara kesehatan. Selain itu, berdasarkan hasil penelitian yang di lakukan oleh Nindatu et al, (2016 ), biji lamun mengandung karbohidrat sebanyak 59,26\%, protein 5,65\%, dan juga antioksidan yang sangat bermanfaat bagi kesehatan tubuh . Dengan demikian sudah sangat jelas bahwa biji lamun sangat kaya akan nilai gizi sehingga sangat disayangkan jika tidak di olah secara baik. Selain itu diharapkan masyarakat tidak hanya memanfaatkan buah lamun, tetapi juga dapat menjaga kelestarian ekologi lamun yang juga menjadi tempat berlindung dan tempat mencari makan oleh ikan dan hewan bentos lainnya. Implikasi hasil penelitian ini dibuat dalam bentuk media pemebelajaran berupa leaflet yang disebarkan kepada masyarakat pesisir di pulau Osi sehingga dapat menjadi bahan informasi dan pembelajaran bagi masyarakat agar dapat memanfaatkan buah lamun sebagai bahan pangan alternatif sekaligus melakukan konservasi secara insitudengan lebih baik.

\section{KESIMPULAN}

Terdapat perbedaan yang signifikan antara tepung 0 bulan (tanpa penyimpanan) dengan tepung yang di simpan selama 2,4 dan 6 bulan dengan nilai signifikan 0.000, sehingga dilanjuti dengan uji tuckey yang menunjukkan nilai kadar serat kasar tertinggi pada lama penyimpanan 0 bulan dengan nilai 2.8733 dan nilai kadar serat kasar terkecil pada lama penyimpanan 6 bulan dengan nilai 2.0467 hasil ini menunjukkan bahwa 
semakin lama penyimpanan tepung biji lamun akan berpengaruh pada kadar serat kasar pada tepung biji lamun.

\section{SARAN}

Perlu adanya penelitian lanjutan mengenai kadar air pada tepung biji lamun berdasarkan lama penyimpanan dan teknik pengeringan.

\section{KEPUSTAKAAN}

Almatsier, S. 2009. Prinsip Dasar Ilmu Gizi. PT Gramedia Pustaka Utama. Jakarta

Apriyanti, T. 2010. "Kajian Sifat Fisikokimia Dan Sensori Tepung Ubi Jalar Ungu (Ipomoea batatas blackie) Dengan Variasi Proses Pengeringan”. Skripsi S1.Program Studi Teknologi Hasil Pertanian.Universitas Sebelas Maret. Surakarta. Fakultas Pertanian

Arief, M. E. Kusumaningsih dan B. S. Rahardja. 2008. Kandungan protein kasar dan serat kasar pada pakan buatan yang difermentasi dengan probiotik. Berkala Ilmiah Perikanan Vol. 3 No. 2.

Badan Standarisasi Nasional. 1995. Tepung Jagung. SNI 01-3727-1995. Hal. 2.

Bell and North, M. O. 1990. Commercial Chicken Production Manual. $4^{\text {th }}$ Edition. Chapman and Hall. New York.

Brooker, D. B, F.W. Bakker Arkema and C.W. Hall. 1992. Drying and Storage of Grains and Oilseeds. AVI Pub. Co. Inc. Connecticut. New York

Chung, M.S., R.R. Ruan., P. Chen., S.H. Chung., T.H. Ahn, and K.H. Lee. 2000. Study Of Caking In Powdered Foods Using Nuclear Magnetic Resonance Spectropy. $J$. offood Sci., 65(1):1.

Den Hartog, 1970. The seagrass of the world. North Holland Publishing Company. London.

Fennema, O. R. 1985. Food Chemistry. Marcel Dekker, Inc. Cleveland

Hasanuddin, R. 2013. Hubungan Antara Kerapatan Dan Morfometrik Lamun Enhalus Acoroides Dengan Substrat Dan Nutrien Di Pulau Sarappo Lompo Kab.Pangkep. Skripsi. Jurusan Ilmu Kelautan, Fakultas Ilmu Kelautan Dan Perikanan Universitas Hasanuddin. Makassar.

Hermayanti, Yeni, Eli Gusti. 2006. Modul Analisa Proksimat. SMAK 3 Padang. Padang. Indrianty, Y. 2010. Higiene Dan Sanitasi Pengolahan Roti Pada Pabrik Roti Di Desa Kampung Lalang Kecamatan Sunggal Medan. Skripsi. Fakultas Kesehatan Masyarakat. Universitas sumatera utara medan (online), 30 hal

Kartining, T. Permana Sari, 2012. Pemanfaatan Tepung Biji Nangka (Artocarpus heterophillus lamk), Serbagai Subtitusi Dalam Pembuatan Kudapan Berbahan Dasar Tepung Terigu Untuk PMT Pada Balita (Kajian Terhadap Analisis 
Proksimat Serta Sifat rganoleptiknya). Skripsi. Jurusan Ilmu Kesehatan Masyarakat. Fakultas Ilmu Keolahragaan. Universitas Negeri Semarang.

Kiswara, W. 2009. Tinjauan Tentang Lamun di Indonesia.Makalah disampaikan Pada Lokarya Nasional 1 Pengelolaan Ekosistem Lamun 'Peran Ekosistem Lamun dalam Produktivitas Hayati dan Meregulasi Perubahan Iklim'. 18 November. 2009. PKSPL-IPB, DKP, LH, dan LIPI. Jakarta.

Kusnandar, F. 2010. Mengenal Serat Pangan. Departemen Ilmu dan Teknologi Pangan, IPB. Bogor 